Marquette University

e-Publications@Marquette

College of Education Faculty Research and

Publications

Education, College of

$1-1-2017$

De los Derechos Humanos: Reimagining Civics in Bilingual \& Bicultural Settings

Melissa L. Gibson

Marquette University, melissa.gibson@marquette.edu

Accepted version. The Social Studies, Vol. 108, No. 1 (2017): 10-21. DOI. (C) 2017 Taylor \& Francis (Routledge). Used with permission. 
Marquette University

e-Publications@Marquette

Education Faculty Research and Publications/ College of Education

NOT THE PUBLI SHED VERSION; this is the author's final, peer-reviewed

manuscript. The published version may be accessed by following the link in the citation below.

The Social Studies, Vol 108, No. 1 (2017): 10-21. DOI. This article is $\odot$ Taylor \& Francis (Routledge) and permission has been granted for this version to appear in ePublications@Marquette. Taylor \& Francis (Routledge) does not grant permission for this article to be further copied/distributed or hosted elsewhere without the express permission from Taylor \& Francis (Routledge).

\section{DE LOS DERECHOS HUMANOS: REIMAGINING CIVICS IN BILINGUAL \& BICULTURAL SETTINGS}

Melissa Leigh Gibson

Department of Education, Marquette University, Milwaukee, WI

\section{ABSTRACT}

Dominant approaches to teaching social studies often marginalize bilingual and bicultural students. This is particularly troubling because the explicit goal of the social studies is to cultivate civic participation. Educational inequalities are thus tied to political inequalities. In light of this, this article shares a narrative case study of the author's own bilingual and bicultural approach to teaching middle school civics at a dual-language American school in Mexico. Through the illustration of a comparative civics curriculum that incorporates translanguaging practices, the author argues that embracing bilingualism and biculturalism in the social studies can lead to more expansive possibilities for justice-oriented civic education.

KEYWORDS: Civics, bilingualism, human rights, social justice, international education

Twenty years ago, James Loewen (1995) noted in Lies My Teacher Told Me,

Students consider [social studies] 'the most irrelevant' of twenty-one subjects commonly taught in high school. Bor-r-ring is the adjective they apply to it...African American, Native 


\section{American, and Latino students view history with a special dislike. They also learn history especially poorly... Something intriguing is going on here: surely history is not more difficult for minorities than trigonometry or Faulkner (p. 2).}

Loewen's observations remain relevant today. Critics have continued to argue that the lies and omissions about race and injustice embedded in social studies marginalize students of color (Brown, 2010; Cammarota, 2007; Cridland-Hughes \& King, 2015; Grant, 2011; Ladson-Billings, 2003; Romero, Arce, \& Cammarota, 2009; Yosso, 2005). Considering that the social studies' primary purpose is to cultivate democratic citizens - "the promotion of civic competence" (NCSS, 2010) -the long-term consequences of student disengagement will also be citizen disengagement (García Bedolla, 2012; Levinson, 2016).

Spanish-speaking Latino students also face a deficit view of their bilingualism, a form of "subtractive schooling" that denigrates their identities (Valenzuela, 1999). The dominant bilingual approach in U.S. schools emphasizes English fluency and cultural assimilation at the expense of students' home language and culture, giving students "the message that the language that they speak is not important, and something that is so much a part of who they are-their community-is outlawed in school" (Izquierdo, 2011). The systematic denigration of students' linguistic and cultural assets through curriculum and language policy are well documented (e.g., García Bedolla, 2012; Romero et al. 2009; Valencia, 2011), as is the fact that Latino students have some of the lowest educational attainment levels in the United States (U.S. Department of Education, 2011). This is especially troubling given that Latinos, a significant number of whom identify as bilingual or Spanish-speaking (Spanish speakers make up 73\% of the ELL population in the United States; see Batalova \& McHugh, 2010), are the fastest growing segment of the school-age population in the United States (Brown, 2014; García Bedolla, 2012). Spanish-speaking students are poorly served civically and linguistically, which comes to a head in the social studies classroom.

What can social studies teachers do to counteract these forces within the classroom? Using my own eighthgrade, dual-language civics classroom in Guadalajara, Mexico, as a case study, I show how embracing bilingualism and biculturalism can lead to more expansive possibilities for justice-oriented social studies in a changing world. This is not an empirical study but rather a narrative of teaching practice that can help reimagine what civic education can be in bilingual and bicultural settings.

\section{Reviewing the literature on civics and bilingual education}

According to the National Council of the Social Studies (2010), "The primary purpose of social studies is to help young people make informed and reasoned decisions for the public good as citizens of a culturally diverse, democratic society in an interdependent world." Yet in practice, social studies-for-citizenship is often narrowed to a thin understanding of civics and citizenship, one that emphasizes a banking model of fact-based government education and that "fails to reflect the continual struggles of democratic politics" (Abowitz and Harnish, 2006).

There are, however, alternative approaches. For example, Parker (2010) argues for a social studies curriculum that teaches toward enlightened political engagement-reflective citizenship that moves back and forth between knowledge and action. To this end, civic education should emphasize public deliberation and talking across difference. Alternatively, Fránquiz and Brochin-Ceballos (2006) focus on Mexican American students and urge educators to draw on cultural citizenship, which "shifts the meaning of citizenship from strict rights to students' evolving sense of belonging to differing social groups and to claiming cultural space for personal and 


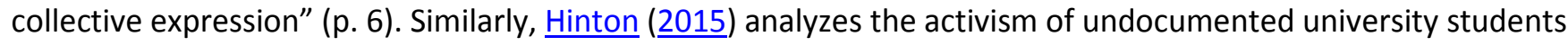
to argue that the role of educational institutions is to encourage active citizenship rather than mere legal citizenship. Active citizenship is "conceptual, behavioral, and nuanced; active citizenship encompasses ideas as varied as civic engagement, political activism, a sense of belonging, cultural commonality, community, patriotism, virtue, and critical consciousness" (p. 154). Finally, Westheimer and Kahne (2004) distinguish between personally responsible citizens, participatory citizens, and justice-oriented citizens. Although all three are active in their communities, only justice-oriented citizens understand that "to solve social problems and improve society, citizens must question, debate, and change established systems and structures that reproduce patterns of injustice over time" (p. 240).

How do schools cultivate action- and justice-oriented citizens? One of the most common approaches is service learning, which marries community service with academic study of related topics (e.g., Bloom, 2003; Chill, 2009; Fehrman \& Schutz, 2011; Levinson \& Levine, 2013; Percoco, 2015; Ponder, Veldt, \& Lewis-Ferrell, 2011). Youth participatory action research (YPAR) is another framework intended to cultivate both agency and knowledge. In YPAR students use the tools of social science to investigate issues in their communities that they themselves identified, and they use their research findings to work for community change (e.g., Cammarota and Romero, 2009; Hubbard, 2015; Irizarry, 2009). YPAR is one way of bringing to life Journell, Walker Beeson, and Ayers's (2015) finding that high-quality civics education equips students to be critical consumers of political knowledge and that this is done through the teaching and application of the disciplinary tools of the social sciences. Osler (2015) similarly argues that combining official curricula with learners' own experiences, identities, and values is essential for the cultivation of active citizens. Ultimately, high-quality civic education asks, "What should we do?" (Levine, 2016) and then works to develop students' critical consciousness through critical reflection and civic action (Diemer \& Rapa, 2016).

Yet opportunities to access a high-quality civic education are limited for students of color and low-income students. They are not given as many opportunities to study topics that matter to them, to take action in their communities, to participate in school governance, to partner with civic leaders, or to become leaders themselves (Kahne \& Middaugh, 2008). Moreover, the "master narrative" of social studies curricula privileges the perspective of dominant groups. Although there are approaches to social studies that encourage students to think critically about dominant narratives (e.g., Salinas, Blevins, \& Sullivan, 2012), this is not the norm (e.g., Cherryholmes, 1978; Cridland-Hughes \& King, 2015b; Ladson-Billings, 2003).

For Spanish-speaking Latino students, this inequality of access to high-quality civics education is compounded by the subtractive nature of bilingual schooling. Yet when considering more expansive forms of citizenship, such as cultural and active citizenship, it is clear that bilingualism is an important tool for civic agency. For example, Stepick, Stepick, and Labissiere (2008) find that deploying bilingualism is in and of itself a form of civic action among immigrants, such as when immigrants translate to help one another navigate new contexts. While Latino youth are aware of the ways in which racial and linguistic stereotypes serve to delegitimize their citizenship (Bondy, 2016), they also use their bilingualism as a form of resistance (Walsh, 1987).

In contrast, a culturally and linguistically relevant social studies education would invite students to engage in their own cultural and linguistic practices within "official" schooling experiences. Teachers can support this through pedagogical and curricular approaches that emphasize critical literacy, social justice, global studies, authentic intellectualism, critically conscious caring, and translanguaging (e.g., García et al., 2012; Jaffee, 2016; Romero, Arce, \& Cammarota, 2009; Salinas, 2006; Salinas, Blevins, \& Sullivan, 2012). 


\section{Teaching context}

This pedagogical narrative is uniquely situated in relation to bilingualism and civic education. The school where this case takes place is an American school located in the central city of Guadalajara, Mexico, serving roughly 1,500 students from nursery through twelfth grade (ages 3-19). Being a U.S. Department of State-sponsored institution in Mexico, the American School offers a dual-language, dual-program curriculum. Roughly two-thirds of the school day is an American-style curriculum conducted in English; the other one-third is the official Mexican curriculum, overseen by the Mexican government's Secretaria de Educación Publica and conducted in Spanish. When students graduate, they receive both American and Mexican diplomas.

Students at the American school are predominantly Mexican. In my classes, roughly $90 \%$ of students were Mexican citizens and native Spanish speakers. The remaining $10 \%$ were international students who were in Guadalajara because of parents' work (foreign teachers, American consulate employees, international business leaders, or professional athletes); Spanish was a second language for these students, with most speaking English or Korean at home. The American School is considered one of the most exclusive schools in Guadalajara, and most of my Mexican national students were members of Guadalajara's economic elite. Tuition is high, and admission depends in part on knowing families already within the school. While the majority of students go to college and make their careers in Mexico, they still find a bilingual, American-style school affords cultural, social, and economic capital.

The school's faculty is split roughly 50/50 between Mexican national teachers and international teachers from the United States, Canada, and the United Kingdom. I am an American teacher who moved to Mexico with 12 years of experience as an educator in secondary and university settings, in both urban and suburban schools. However, this was the first time that I had taught in a fully bilingual setting. I was in the process of learning Spanish while living in Mexico.

My course-eighth-grade civics - was within the American program, which emphasized traditional U.S. and world history courses. The Grade 8 civics course fell in the middle of four years of world history in Grades 6, 7, 9, and 10. While my teaching was guided by standards (Common Core and AERO) and textbooks (McGraw Hill's Building Citizenship: Civics \& Economics), teachers within the middle school were encouraged to see these as tools to build relevant curriculum, particularly in consort with the school's strong service-learning program. My teaching thus built from the critical literacy focus of the Common Core, the emphasis on active citizenship in the McGraw Hill textbook, and the community's commitment to service learning. However, my teaching was also inspired by the approach to civics in the Facing History \& Ourselves program (Fine, 1991/1992), as reimagined in Louisville, Kentucky's, public schools ("Exploring Civics: Facing History in Kentucky | Facing History and Ourselves," 2016). I wanted students to develop a critical consciousness about political and social narratives and to develop a vision of themselves as citizens capable of working for positive change in the communities they belong to-not as a future aspiration, but now. To that end, our study of civics was driven by essential questions that transcended national context:

- In a democracy, what is the relationship between citizens and their communities?

- How does social change happen, and what role do citizens have in catalyzing it?

- What would it take to make our own communities more just and equitable?

We answered these questions through a series of units on critical media literacy, systems of government, a case study of U.S. democracy, a case study of Nazi totalitarianism, a comparative study of rights documents, and 
global movements for social change (Table 1). The narrative that is shared here focuses specifically on the comparative rights unit and the ways in which drawing on our bilingualism and biculturalism as civic assets allowed us to engage in civic learning that was linguistically and culturally relevant for my students and potentially transformative for their identities as citizens.

Table 1. Civics curriculum and social issues project curriculum map.

\begin{tabular}{|c|c|c|c|c|c|c|}
\hline & Aug. & & Nov. & & Mar. Apr. & May June \\
\hline $\begin{array}{l}\text { Civics } \\
\text { Curriculum }\end{array}$ & $\begin{array}{l}\text { Citizens \& } \\
\text { Communities | } \\
\text { Exploring the } \\
\text { communities } \\
\text { we belong to, } \\
\text { their values, } \\
\text { and how we } \\
\text { can } \\
\text { contribute. }\end{array}$ & $\begin{array}{l}\text { Informed } \\
\text { Citizenship \& } \\
\text { Media Literacy } \\
\text { | Learning to } \\
\text { read the news } \\
\text { critically \& } \\
\text { exploring the } \\
\text { role of the } \\
\text { press in } \\
\text { democratic } \\
\text { citizenship. }\end{array}$ & $\begin{array}{l}\text { Forms of } \\
\text { Government I } \\
\text { Researching } \\
\text { different } \\
\text { political } \\
\text { systems with an } \\
\text { emphasis on } \\
\text { the structure of } \\
\text { governments } \\
\text { and political } \\
\text { ideologies. Case } \\
\text { study of US } \\
\text { democracy. }\end{array}$ & $\begin{array}{l}\text { Why Active \& } \\
\text { Informed Citizens } \\
\text { Matter I } \\
\text { Analyzing the } \\
\text { consequences of } \\
\text { citizen (in)action } \\
\text { through a case } \\
\text { study of Nazi } \\
\text { Totalitarianism. }\end{array}$ & $\begin{array}{l}\text { Democracy \& } \\
\text { Human Rights | } \\
\text { Exploring } \\
\text { democratic } \\
\text { government \& } \\
\text { citizens' rights } \\
\text { through a } \\
\text { comparative } \\
\text { case study of } \\
\text { the } \\
\text { constitutions of } \\
\text { the US and } \\
\text { Mexico and the } \\
\text { Universal } \\
\text { Declaration of } \\
\text { Human Rights. }\end{array}$ & $\begin{array}{l}\text { Citizens \& } \\
\text { Social Change } \\
\text { | Exploring } \\
\text { the role of } \\
\text { citizens and } \\
\text { policy in } \\
\text { making } \\
\text { positive social } \\
\text { change } \\
\text { through } \\
\text { global } \\
\text { movements } \\
\text { for social } \\
\text { change. }\end{array}$ \\
\hline $\begin{array}{l}\text { Social } \\
\text { Issues } \\
\text { Project }\end{array}$ & $\begin{array}{l}\text { Identifying our } \\
\text { communities } \\
\& \text { the issues } \\
\text { within them. }\end{array}$ & $\begin{array}{l}\text { Tracking } \\
\text { current events } \\
\text { on the social } \\
\text { issues that } \\
\text { affect our } \\
\text { communities } \\
\text { (Critical Media } \\
\text { Literacy). }\end{array}$ & $\begin{array}{l}\text { Background } \\
\text { research on our } \\
\text { chosen social } \\
\text { issue \& asking a } \\
\text { Big Question } \\
\text { about that issue } \\
\text { (QAR \& } \\
\text { Research } \\
\text { Tools). }\end{array}$ & $\begin{array}{l}\text { Learning how } \\
\text { individuals \& } \\
\text { organizations are } \\
\text { working for } \\
\text { change around } \\
\text { our social issue } \\
\text { (Four Legs of the } \\
\text { Stool), and } \\
\text { connecting with } \\
\text { local resources. }\end{array}$ & $\begin{array}{l}\text { Raising } \\
\text { awareness and } \\
\text { taking action on } \\
\text { our social issue. }\end{array}$ & $\begin{array}{l}\text { Authoring } \\
\text { iBooks on our } \\
\text { social issue. }\end{array}$ \\
\hline
\end{tabular}

\section{Bilingual and bicultural civics in action: a teaching narrative}

During one of our weekly Friday Trivia games, my students were stumped by this question: Where does Mexico's GDP rank globally? Their guesses were low-52nd, 75th, 180th (there were 191 countries ranked in the World Bank's online index of domestic products). They were shocked to learn that in this global comparison of economies, their country ranked 15th in the world, just after the Republic of Korea. "No way, Miss! Korea is a


notes

This was not the first time that my students were shocked at what we learned about Mexico. When they saw their recently elected president, Enrique Peña Nieto, on the cover of Time magazine, they scoffed: "Our 
president is dumb. He can't even speak English!" When we read about a 12-year-old Mexican girl billed as the "next Steve Jobs" in Wired magazine, César was incredulous: "But no one learns anything in our schools." When we saw data showing that in recent years there had been more migration from the United States to Mexico than the other way around, Alma was confused: "Why would people come here?"

This anti-Mexico commentary sounded more like what I would expect from U.S. cable news than from a room of Mexican teenagers. While my students were quick to contest American stereotypes of Mexico, they also perpetuated their own every time they wondered, "Miss, why are Mexicans so lazy and uneducated?"

There were many reasons for my students' uncritical acceptance of these stereotypes. Our media, even in Mexico, was saturated with American perspectives. My wealthy students also boasted American aspirations-in fashion, travel, college, employment. Our city's colonial history meant we lived with deeply entrenched racial and social hierarchies. This context was compounded by our American school curriculum, both official and hidden. It is, after all, the status afforded by an American-style, English-language education that led many families to choose our school instead of Mexican schools, which were widely perceived as failures. I wanted students to critically interrogate these community contexts-and to draw on their straddling of different worlds and languages as an asset in doing so.

\section{Understanding our rights}

As we dug into traditional civics content, students constantly asked questions comparing rights in the United States and Mexico: "Miss, do we have a Bill of Rights in Mexico?" "Did Americans invent the freedom of speech?" To answer these questions, I designed a unit in which students compared U.S. and Mexican conceptions of rights as framed in each country's Constitution. Before we turned to the documents, we brainstormed: What rights should all citizens have? What guarantees do we deserve as members of a community-or simply because we are human? Students prioritized safety: the right to live safely and securely, the right to be free of government and police harassment, and the right to live free of violence. These were pressing concerns in our local context where corruption, state violence, and disappearances were regular occurrences. Students also named the right to be healthy, specifically with access to clean water; the right to food and shelter; the right to education; and the right to liberties such as freedom of thought and speech. Students' priorities reflected those rights that they felt were violated in Mexico and therefore needed protection, and these perceptions were informed by both their own daily lives and the events they read about in their weekly study of current events: the deadly pollution of the Río Santiago; the arrest of the national teachers' union leader for embezzlement; the disappearance and murder of the Iguala 43; the constitutional reforms of 2014. I encouraged students to read the news in Spanish as well as English, both because different stories were covered (there are no articles about the Río Santiago in American newspapers) and because it invited comparison of news coverage in the United States and Mexico.

After developing a list of what we considered fundamental rights, we turned to the U.S. Bill of Rights. We compared these 10 rights to our brainstorm, and we predicted whether these were also protected in Mexico. While most students said, "Uh, Miss, we don't know what our Mexican rights are," a few were certain that liberties such as the freedom of speech were not guaranteed in Mexico, and virtually all believed they had fewer rights than Americans.

Next, we turned to the Mexican Constitution. Most students read it in its original Spanish, but students who were not proficient in Spanish were given access to an English translation. Mexico's Constitution begins with 
rights: “De los Derechos Humanos y sus Garantías" (“On Human Rights \& Their Guarantees”), with Title I listing 38 articles describing citizens' rights and responsibilities. This alone surprised my students. At first they complained, "We have to read all of this?" But their frustration quieted down when they realized what the document contained. Students had been certain that Mexico had a lack of rights, but the Constitution showed them that, at least on paper, this wasn't true. Right off the bat, the Constitution of Mexico begins by outlawing slavery (Article 2), guaranteeing education (Article 3), and protecting workers' rights (Articles 4 and 5). With the exception of the abolition of slavery, these are not rights guaranteed by the U.S. Constitution or its amendments. As we continued to compare documents, students were surprised to see that the Mexican Constitution guaranteed far more types of rights than the U.S. Bill of Rights.

Several realizations grew from this comparison. For one, when we looked back at our original brainstorming, we began to see that the very idea of rights is shaped by culture and context. Students' inclusion of not merely civil and political rights but also social and economic rights (e.g., the right to food and shelter) in their initial brainstorm revealed the influence of their own cultural context in Mexico. Seeing that context affects values led to a student-driven mini-exploration of the historical context of each document's writing; they were encouraged to access information in both Spanish and English. Students were quite surprised to learn that Mexico's was the first constitution to codify social rights, and they began to see the image of the United States as a "free" country and Mexico as one without rights as inaccurate. However, they also struggled to reconcile these documents with their lived experiences-experiences that included racial and linguistic discrimination in the United States and corruption and disregard for rights in Mexico.

\section{Introducing human rights}

"Okay, Miss," Roberto challenged me. "Who decided that these are our rights? And how come not everyone gets them? If I disagree with the government, I do not have the freedom of speech in Mexico-I might get murdered!" Alma chimed in, "Yeah-and what if I'm not in Mexico? Do I still have my rights? I am pretty sure I have no rights in the US since I am Mexican." Ana Paula, who was in the throes of preparing for a Model United Nations conference and had been researching human rights, sighed heavily. "You guys. There is such a thing as human rights. We have human rights, too."

"Well, then," Roberto persisted. “Why doesn't our government respect human rights?"

A good question, but one that required understanding what human rights are and how they are connected to the rights included in national constitutions. Although the Universal Declaration of Human Rights is a controversial document, its articulation of fundamental rights can become a foundation for a deeper understanding of and work toward social justice, even in local communities. Particularly among the economically privileged students that I taught, our study of human rights became a tool for seeing how the taken-for-granted inequities in our society were not merely individual experiences but instead threats to collective rights.

We began by distinguishing between human rights and constitutional rights. I asked students to consider what makes us human and why that humanity warrants a specific set of rights. This is a hard question for eighth graders, but through group discussion and an introduction to philosophical thinking (e.g., a one-paragraph excerpt from Hanna Arendt; a YouTube video on Rousseau and Locke), they developed a set of traits that seemed to be uniquely human: Humans have a sense of morality, empathy, and conscience; humans have a need to tell stories about their lives and to make meaning from those stories; and humans strive for something 
bigger from life than mere survival, or the idea of self-actualization. We then debated these human characteristics using a Four Corners activity. Around the room were signs, each listing one uniquely human trait we had identified. Students had to stand by the trait that they felt was the most uniquely human and then defend that choice during small group debates. In this forced choice activity, student reasoning congealed around self-actualization.

To explore the relationship between self-actualization, basic needs, and guaranteed rights, I introduced Maslow's (1943) hierarchy of needs, one (admittedly problematic) model for making sense of the needs and desires that make us human. In Maslow's hierarchy, the mid-century psychologist ranks human needs from the most foundational-physiological and security-to more intangible needs related to love, belonging, esteem, and self-actualization. After introducing this framework, I asked students to consider whose responsibility it was to ensure that these needs were met. Did humans have the ability to meet all of these needs individually? Did some needs, such as safety and love, require community to be fulfilled? If so, what role might communities play in protecting or preventing the realization of these needs?

We then turned to current events coverage of human rights issues in Mexico, such as President Peña Nieto's proposed telecom reform of 2014, which sought to grant the government more censorship rights during events deemed a national crisis. Students considered how this law might affect citizens' rights. Always wise Roberto observed, "Well, how can I have security if the government has the right to take away that security when it wants to?" Thus, Maslow's hierarchy, however flawed, gave students a language for connecting communities, governments, and human dignity. It is most important that students began asking, if all humans have common needs and desires, what prevents us from achieving them?

Finally, we turned to the Universal Declaration of Human Rights (UDHR). As with the national constitutions, we carefully read all 30 articles and compared them to those included in the U.S. and Mexican Constitutions.

Students were surprised to see that there was far less overlap between the UDHR and the U.S. Bill of Rights than with the Mexican Constitution. Students hotly debated one another as they worked in partners to map all 30 articles of the UDHR onto a diagram of Maslow's hierarchy. This contentious process allowed students to see that both the Mexican Constitution and the UDHR covered a variety of human needs - with Article 26 of the UDHR explicitly talking about self-actualization-but that the civil liberties guaranteed in the United States dealt only with certain types of security and esteem. This confused my students. Octavio wondered, "Isn't the US supposed to be more free than Mexico?"

This is a provocative question given the history of how human rights were codified at the United Nations. The United States, although a leader in calling for the codification of human rights, reluctantly ratified the UDHR, in part because of its inclusion of social rights like those in the constitutions of Mexico and other Latin American countries (see Anderson, 2003; Glendon, 2001; Morsink, 1999). This history, woven into our study of the UDHR, continued to upend students' ideas of the United States as inherently more "free" than Mexico. This history also illustrated how the modern concern for human rights was born out of lived injustice-genocide, war, colonization, and racial inequality. But just as important as the historical context of the UDHR was the historical context of the U.S. and Mexican Constitutions, which were born of particular political and economic struggles. Students investigated each of these contexts - the American Revolution, the Mexican Revolution, and World War II-to interrogate how particular ideas of rights were born from these struggles. 


\section{A call to action}

Our academic study of constitutional and human rights became a call to action. Students began asking, if food, shelter, and living wages are human rights, why is there so much poverty in Mexico? If Mexicans have freedom of speech and the right to protest peacefully, why has the government been limiting those rights? If we all have the right to move freely, then isn't the migration crisis in the Americas a violation of human rights? If health is a human right, shouldn't access to clean water be guaranteed? Students began to see rights not only as promises of justice but also as reminders of how those promises are broken.

This developing critical perspective transformed work on our yearlong Social Issues Project (see Table 1). This research-intensive project had previously been met with groans, but now students began to see advocacy and action in their communities not simply as a school project but as their duty to defend human rights. Many projects shifted from being intensely local to connecting with national and global issues, with students choosing issues related to environmental problems, public health issues, poverty and inequality, education, statesponsored violence, human trafficking, and gender equality, among others. In that, the Social Issues Project became a way to practice transnational citizenship, which emphasizes civic action in the local, national, and global spheres (Abowitz \& Harnish, 2006).

Over the course of the project, students learned what a social issue is, tracked news in their communities in both Spanish and English, and then selected a social issue to investigate and take action on. The project culminated in the production of awareness-raising iBooks published in the iTunes store. Students also conducted in-depth research on their chosen issues, which included the identification of who was working for change at the local, national, and international levels. All of this required them to draw on their bilingualism and their ability to navigate different cultural contexts.

In response to our study of human rights and comparative civics, students' approaches to both the social issues and their role in creating change grew more complicated. For example, Luz had chosen to investigate child labor in Mexico. As we studied the concept of human rights, Luz's sense of urgency around this issue grew from sympathy to an understanding of her shared fate with child laborers: "People in Mexico should care about child labor because it is a violation of their rights as human beings...If we dare to call ourselves Mexicans that follow the Constitution, then we should fight for our people's rights, our kids' rights."

Similarly, after reading the UDHR, other students began to pay attention to issues that had not previously been on their radar. As we discussed the freedom of movement, we read about the migration crisis in Central and North America, both in U.S. news coverage and through Spanish-language narratives. Guadalajara is a major waypoint for migrants on their journey to the U.S. border. As a result, a group of students decided to start working with a local NGO providing food, shelter, and medical services to Central American migrants passing through Guadalajara. Other students noted the lack of attention to environmental issues in the UDHR and argued that things such as access to clean water and air should be human rights. As a result, they investigated who was working on environmental change in our state, Jalisco. Some students partnered with a national NGO reforesting Guadalajara's wild spaces, while others joined grassroots efforts to clean up the Río Santiago.

The study of human and constitutional rights introduced many of my quite-sheltered students to social issues they had never before experienced. It also pushed students to see the interconnectedness of social problems and to explore systemic solutions rather than the kind of individualized direct service they were used to doing in our service-learning program, such as planting trees or bringing school supplies to low-income communities. 
Students began to consider instead how citizens contribute to lasting social change through advocacy, partnerships, and organizing.

\section{Discussion: bilingualism and biculturalism as civic assets}

Bilingualism in schools is most often presented as double monolingualism, or the artificial separation of languages (García, Flores, \& Woodley, 2015). Yet in reality, bilingual students draw on their languages in fluid, flexible, and interconnected ways - what is known as translanguaging (García, 2014). Similarly, students' bicultural identities are often pushed into silos at school even though their lived experience is one where they always occupy multiple identities at once. In contrast, this reimagined civics curriculum embraced students' bilingualism and biculturalism. Operating within both linguistic and cultural spheres simultaneously pushed us to deconstruct dominant narratives around citizenship and to see the pitfalls, challenges, and opportunities in each context. Deploying their bilingualism and biculturalism to gather information, to communicate, and to think critically empowered students to contribute to social change in border- and community-crossing ways.

By explicitly asking students to draw on their experiences living within two communities, I was able to create curricular space for naming and investigating the dissonances we all lived on a daily basis. Putting on our American lenses to examine Mexican citizenship and our Mexican lenses to explore American citizenship allowed us to see more vividly where civic ideals may not align with lived experience. For example, we were able to interrogate the reality of Mexican corruption versus the promises of democracy in the Mexican Constitution and to critique American exceptionalism in light of the U.S. Constitution's omission of many human rights. Our bilingualism and biculturalism enabled us to see the invisible ways that dominant narratives work to mask injustice, inequality, disenfranchisement, and neglect.

In this process I encouraged students to engage in the translanguaging practices that more authentically represented their bilingualism. We drew on news coverage, political documents, and social networks in both languages to broaden our ideas of fairness, justice, and human dignity. While I taught in English and our shared class language was English, students used whatever languages they were comfortable with to access, process, and communicate information. They moved fluidly between Spanish and English documents, Web sites, and conversations, and doing so gave them a depth of understanding that forced monolingualism in the classroom never could have. For example, when I shared English-language articles about Peña Nieto's proposed constitutional reforms of 2014, students wondered why they hadn't heard much about this. They turned to Spanish-language news, where coverage was limited. We then looked to digital media for debates about the reforms and learned that while Americans and Europeans saw them as a welcome move toward economic liberalization, many Mexicans saw them instead as a consolidation of power and the strengthening of government impunity. This in turn led to questions about the values underlying each country's government structures, such as the different approaches to constitutional amendments.

In fact, one of our most probing conversations was around the word "impunity," which was used frequently by native Spanish-speakers when talking about Mexico's government in English. Yet in English-language discussions of government (whether in Mexico or elsewhere), it was a word we rarely encountered. Together, we theorized what that word choice told us about cultures and governments in each context. We had similar conversations around the use of the words "security" and "safety" in English and Spanish. The practices of translanguaging-of moving fluidly between languages and deploying them in authentic ways that are embedded in social and cultural context-allowed us to access, filter, and communicate information in ways impossible in a doubly 
monolingual curriculum. This in turn began to transform our understandings of injustice, inequality, and social change.

\section{Conclusion}

My goal for students was not only to gain knowledge about different constructions of democratic citizenship and to acquire social science tools that they could use as citizens working for real change in their communities but also to develop a sense of shared fate with the diverse members of our communities-and to see their bilingualism and biculturalism as important tools in that process. In our American school bubble, students were often disconnected from the issues facing our communities and only engaged with less privileged communities in ways that helped them see themselves as "good people" (see Gaztimbe-Fernandez \& Howard, 2010). Yet justice-oriented citizenship demands a shift from individual motivation to a sense of collective efficacy for social change.

My students could not have developed that sense of collective efficacy without being encouraged to engage in authentic practices of translanguaging. By drawing on their varied linguistic repertoires and by collectively questioning ideas of citizenship in different contexts, students practiced within the classroom the kind of collective meaning-making that we want them to do in their communities. The act of working across language and culture in the classroom was itself a civic act. Fluidly moving between language and culture in spontaneous ways made visible the contextual underpinnings of citizenship; it also made visible the inconsistencies and inequities in the dominant narratives of national citizenship in Mexico and the United States. This process certainly benefitted the students who were themselves engaging in translanguaging practices, but it also benefitted monolingual and monocultural students in that it made visible their own contextualized perspectives and experiences. As students engaged in the curriculum together, they experienced through language practices how interdependence develops.

If the goal of civic education is to cultivate active citizens who marry deep social science knowledge with justiceoriented community action, then civics teaching must be grounded in the worlds of students themselves. It is, after all, through their languages, identities, and cultures that students make sense of their social worlds. Although this case takes place in a unique context, it still demonstrates how grounding a civics curriculum not only in standards but also in students' own linguistic and cultural contexts invites student engagement, inspires student-driven action, and ultimately challenges dominant narratives that perpetuate inequity. This is particularly important in the U.S. context where students whose first language is not English, especially Spanishspeaking students, are marginalized in schools by both language policies and curriculum.

Within citizenship education, there is a need for more research on bilingual and bicultural settings, particularly those serving marginalized communities in the United States. How do translanguaging practices affect the development of civic identities in classrooms where students do not all share the same linguistic and cultural context? How do translanguaging practices in the classroom affect marginalized students' civic identities? How might embracing multilingual practices in diverse classrooms affect the cultivation of integrated and interdependent communities?

This case also suggests the need for civic educators to build more explicitly comparative and transnational civics curricula. U.S. classrooms are increasingly diverse, and the curriculum should provide opportunities to learn from that diversity. This is, after all, one of the core tenets of a democratic civic education (Parker, 2008). Rather than abandoning the mandated curriculum or standards, these can become a springboard for asking critical 
questions about citizenship and rights and for expanding understandings of global citizenship beyond the labor market. By encouraging students to study citizenship across national contexts, my civics course enabled students to construct their own ideas of justice-oriented citizenship, such as when they began to bristle at negative characterizations of Mexicans. When Inés tried to explain educational outcomes in Mexico as a result of laziness, her classmates raised questions about larger inequalities. When a local community organizer tried to describe the culture of apathy in Mexico that prevented social change, my students asked him to square his perceptions with the Mexican Constitution's unique call to action and activism.

Ultimately, welcoming students' bilingualism and biculturalism in the classroom and building curriculum in response to my students' specific community context expanded our civic imagination-and in doing so, pushed back against the "genesis amnesia" (Brayboy, 2011) of accepting the world and its inequities as "just the way things are." Our bilingualism and biculturalism were not barriers to civic action; to the contrary, they were what inspired it.

\section{Notes}

${ }^{1}$ All student names have been changed.

\section{References}

Abowitz, K. K., \& Harnish, J. (2006). Contemporary discourses of citizenship. Review of Educational Research, 76(4), 653-690. doi:10.3102/00346543076004653.

Anderson, Carol. (2003). Eyes off the prize: The United Nations and the African American struggle for human rights, 1944-1955. New York, NY: Cambridge University Press.

Batalova, Jeanne, \& McHugh, Margie. (2010). Number and growth of students in US schools in need of English Instruction. 1. ELL Information Center Fact Sheet Series. Washington, DC.

Bloom, Elizabeth. (2003). Service learning and social studies: A natural fit. Middle Level Learning, 17, M4-7.

Bondy, Jennifer M. (2016). Latina youth, education, and citizenship: A feminist transnational Analysis. Theory \& Research in Social Education, 44(2), 212-243. doi:10.1080/00933104.2016.1170644.

Brayboy, Bryan McKinley Jones. (2011). Genesis amnesia, indigenous knowledge systems, and indigenous peoples. In Annual Meeting of the American Educational Research Association. New Orleans, LA.

Brown, Anna. (2014). U.S. Hispanic and Asian populations growing, but for different reasons. Pew Research Center FactTank: News in the Numbers. Retrieved from http://www.pewresearch.org/fact-tank/2014/06/26/u-shispanic-and-asian-populations-growing-but-for-different-reasons/.

Brown, Anthony L., \& Brown, Keffrelyn D. (2010). Strange fruit indeed: Interrogating contemporary textbook representations of racial violence toward African Americans. Teachers College Record, 112(1), 31-67.

Cammarota, Julio. (2007). A social justice approach to achievement: Guiding Latina/o students toward educational attainment with a challenging, socially relevant curriculum. Equity \& Excellence in Education, 40(1), 87-96. doi:10.1080/10665680601015153. 
Cammarota, Julio, \& Romero, Augustine. (2009). A social justice epistemology and pedagogy for Latina/o students: Transforming public education with participatory action research. New Directions for Youth Development, 123, 53-65.

Cherryholmes, Cleo H. (1978). Curriculum design as a political act: Problems and choices in teaching social studies. Theory and Research in Social Education, 6(4), 60-82. doi:10.1080/00933104.1978.10506045.

Chill, Abigail. (2009). Get in the groove, let's make a move!: Students in Israel confront a transition with service learning | National Council for the Social Studies. Social Education, 73(1), 31-33.

Cridland-Hughes, Susan Anne, \& King, LaGarrett J. (2015). Killing me softly: How violence comes from the curriculum we teach. In Kenneth Fasching-Varner and Nicholas Hartlep (Eds.), The assault on communities of color: Exploring the realities of race-based violence (pp. 99-102). Lanham, MD: Rowman \& Littlefield.

Diemer, Matthew A., \& Rapa, Luke J. (2016). Unraveling the complexity of critical consciousness, political efficacy, and political action among marginalized adolescents. Child Development, 87(1), 221-238. doi:10.1111/cdev.12446.

Exploring Civics: Facing history in Kentucky | Facing history and ourselves. (2016). Retrieved from https://www.facinghistory.org/exploring-civics-facing-history-kentucky.

Fehrman, Darwyn, \& Schutz, Aaron. (2011). Beyond the catch-22 of school-based social action programs: Toward a more pragmatic approach for dealing with power. Democracy and Education, 19(1).

Fine, Melinda. (n.d.). Facing history and ourselves: Portrait of a classroom. Educational Leadership, December/J, 44-49.

Fránquiz, María E, \& Brochin-Ceballos, Carol. (2006). Cultural citizenship and visual literacy: US-Mexican children constructing cultural identities along the US-Mexico border. Multicultural Perspectives, 8(1), 5-12.

García Bedolla, Lisa. (2012). Latino education, civic engagement, and the public good. Review of Research in Education, 36(March), 23-42. doi:10.3102/0091732X11422666.

García, Ofelia. (2014). Countering the dual: Transglossia, dynamic bilingualism and translanguaging in education. In R. Rubdy and L Alsagoff (Eds.), The Global-Local Interface, Language Choice and Hybridity (pp. 100-118). Bristol, UK: Multilingual Matters.

García, Ofelia, Flores Nelson, \& Homonoff Woodley, Heather. (2015). Constructing in-between spaces to 'do' bilingualism: A tale of two high schools in one city. In J. Cenoz and D. Gorter (Eds.), Multilingual education: Between language learning and translanguaging (pp. 199-224). Cambridge, UK: Cambridge University Press.

García, Ofelia, Homonoff Woodley, Heather, Flores, Nelson, \& Chu, Haiwen. (2012). Latino emergent bilingual youth in high schools: Transcaring strategies for academic success. Urban Education, 48, 798-827.

doi:10.1177/0042085912462708.

Gaztimbe-Fernandez, Ruben A., \& Howard, Adam. (2010). Social justice, deferred complicity, and the moral plight of the wealthy. Democracy and Education, 21 (1), 1-4.

Glendon, Mary Ann. (2001). A world made new: Eleanor Roosevelt and the Universal Declaration of Human Rights. New York, NY: Random House. 
Grant, Carl A. (2011). Escaping Devil's Island: Confronting racism, learning history. Race, Ethnicity and Education, 14(1), 33-49. doi:10.1080/13613324.2011.531979.

Hinton, K. a. (2015). Undocumented citizens: The civic engagement of activist immigrants. Education, Citizenship and Social Justice, 10(2), 152-67. doi:10.1177/1746197915583933.

Hubbard, Brian. (2015). Using action research to engage youth in improving OST programming. Afterschool Matters, no. 22, 32-36.

Irizarry, Jason G. (2009). Reinvigorating multicultural education through youth participatory action research. Multicultural Perspectives, 11(4), 194-99. doi:10.1080/15210960903445905.

Izquierdo, Elena. (2011). Two way dual language eudcation. In Richard Valencia (Ed.), Chicano school failure and success: Past, present and future (3rd ed., pp. 160-172). New York, NY: Routledge.

Jaffee, Ashley Taylor. (2016). Social studies pedagogy for Latino/a newcomer youth: Toward a theory of culturally and linguistically relevant citizenship education. Theory \& Research in Social Education, 44(2), 147183. doi:10.1080/00933104.2016.1171184.

Journell, Wayne, Beeson, Melissa Walker, \& Ayers, Cheryl. (2015). Learning to think politically: Toward more complete disciplinary knowledge in civics and government courses. Theory \& Research in Social Education, 43, 28-67.

Kahne, Joseph, \& Middaugh, Ellen. (2008). High quality civic education: What is it and who gets it? Social Education, 72(1), 34-39. doi:10.4324/9780203841273.

Ladson-Billings, Gloria. (2003). Lies my teacher still tells: Developing a critical race perspective toward the social studies. In Gloria Ladson-Billings (Ed.), Critical race theory perspectives on the social studies: The profession, policies, \& curriculum (pp. 1-11). Charlotte, NC: Information Age Publishing.

Levine, Peter. (2016). The question each citizen must ask. Educational Leadership March, 30-34.

Levinson, Meira. (2016). The civic empowerment ;Gap: Defining the problem and locating solutions. In Lonnie Sherrod, Judith Torney-Purta, \& Constance Flanagan (Eds.), Handbook of research on civic engagement (pp. 331361). Hoboken, NJ: John Wiley \& Sons. doi:10.1007/BF00138862.

Levinson, Meira, \& Levine, Peter. (2013). Taking informed action to engage students in civic life | National Council for the Social Studies. Social Education, 77(6), 339-341.

Loewen, James. (1995). Lies my teacher told me. New York, NY: Simon \& Schuster.

Maslow, A. H. (1943). A theory of human motivation. Psychological Review, 50(4), 370-396.

Morsink, Johannes. (1999). The Universal Declaration of Human Rights: Origins, drafting, and intent. Philadelphia, PA: University of Pennsylvania Press.

Osler, Audrey. (2015). Human rights education, postcolonial scholarship, and action for social justice. Theory \& Research in Social Education, 43(2), 244-274. doi:10.1080/00933104.2015.1034393.

Parker, Walter. (2010). Idiocy, puberty, and citizenship: The road ahead. In Walter Parker (Ed.), Social studies today: Research \& practice (pp. 247-60). New York, NY: Routledge. 
Parker, Walter C. (2008). Knowing and doing in democratic citizenship education. In Linda Levstik and Cynthia Tyson (Eds.), Handbook of research in social studies education (pp. 65-80). New York, NY: Routledge.

Percoco, James A. (2015). Take the journey: Historic place-based service learning projects. Social Education, 79(5), 265-270.

Ponder, Jennifer, Vander Veldt, Michelle, \& Lewis-Ferrell, Genell. (2011). Citizenship, curriculum, and critical thinking beyond the four walls of the classroom: Linking the academic content with service-learning. Teacher Education Quarterly, 38(4), 45-68.

Romero, Augustine, Arce, Sean, \& Cammarota, Julio. (2009). A barrio pedagogy: Identity, intellectualism, activism, and academic achievement through the evolution of critically compassionate intellectualism. Race Ethnicity and Education, 12(2), 217-233. doi:10.1080/13613320902995483.

Salinas, Cinthia. (2006). Educating late arrival high school immigrant students: A call for a more democratic curriculum. Multicultural Perspectives, 8(1), 20-27. doi:10.1207/s15327892mcp0801_4.

Salinas, Cinthia, Blevins, Brooke, \& Sullivan, Caroline C. (2012). Critical historical thinking: When official narratives collide with other narratives. Multicultural Perspectives, 14(1), 18-27.

doi:10.1080/15210960.2012.646640.

Stepick, Alex, Stepick, Carol Dutton, \& Labissiere, Yves. (2008). South Florida's immigrant youth and civic engagement: Major engagement: Minor differences. Applied Developmental Science, 12(February 2015), 57-65. doi:10.1080/10888690801997036.

Task Force of the National Council for the Social Studies. (2010). National Curriculum Standards for Social Studies: A framework for teaching, learning, and assessment. Silver Spring, MD: National Council for the Social Studies.

U.S. Department of Education, and White House Initiative on Educational Excellence for Hispanics. (2011). Winning the future: Improving education for the Latino community. Washington, DC.

Valencia, Richard. (2011). The plight of Chicano students: An overview of schooling conditions and outcomes. In Richard Valencia (Ed.), Chicano school failure and success: Past, present and future (3rd ed., pp. 3-41). New York, NY: Routledge.

Valenzuela, Angela. (1999). Subtractive schooling: US Mexican youth and the politics of caring. Albany, NY: State University of New York Press.

Walsh, Catherine E. (1987). Schooling and the civic exclusion of Latinos: Toward a discourse of dissonance. The Journal of Education, 169(2), 115-131.

Westheimer, Joel, \& Kahne, Joseph. (2004). What kind of citizen? The politics of educating for democracy. American Educational Research Journal, 41(2), 237-269.

Yosso, Tara J. (2005). Whose culture has capital? A critical race theory discussion of community cultural wealth. Race, Ethnicity and Education Ethnicity and Education, 8(1), 69-91. doi:10.1080/1361332052000341006. 